\title{
ACCESS TO ICT EDUCATION FOR GIRLS AND WOMEN IN RURAL SOUTH AFRICA: A CASE STUDY
}

\author{
Nomusa Dlodlo \\ Council for Scientific and Industrial Research \\ Meraka Institute \\ Advanced Institute for Information and Communication Technologies \\ Box 395, Meiring Naude Road \\ Brummeria, Pretoria 0001 \\ South Africa \\ Telephone: (+27-12) 8413190 \\ Fax: (+27-12) 8414570 \\ E-mail: ndlodlo@csir.co.za
}

\begin{abstract}
This paper describes the impact of socio-economic factors on girls and women's access to Information and Communication Technology (ICT) education and training in a rural South African environment and recommends strategies for improved access to ICT education and training. The study was undertaken through a case study conducted in the Mootse village in the Elandsdoorn area of Mpumalanga Province, South Africa.
\end{abstract}

\section{Introduction}

Experience in most countries has shown that women are important actors in the development and to hold them back is to hold back the potential for economic growth. Education is perhaps the primary enabler of women's ability to participate in the development and growth of nations. Information and Communication Technologies (ICTs) have proved to be increasingly fundamental to the socio-economic development of any nation. They are important tools that can provide women access to lifelong learning, education and training. Neglecting to give women access to these tools not only deprives them and their families of income but reduces the skill levels of the nation, limits productivity and bars a country from being competitive in the global market [10]. ICTs are not really about the computer, the Internet and telephone lines but they are about information and communication [16]. It is clear that one cause of low rural income can be blamed on "information poverty" - the lack of access to information and knowledge that could improve earnings potential [11].

This research looks at ways to enhance access to ICT education for girls and women in rural South Africa in line with the UN Millennium Declaration (2000) [17] which resolved to promote gender equality and empowerment of women as effective ways to combat poverty, hunger and disease and to stimulate development that is truly sustainable and to ensure that the benefit of new technologies, especially ICTs, are available to all. It is also in line with the Agreed Conclusions 2003 of the $47^{\text {th }}$ session of the UN Commission on the participation and access of women to the media and ICTs and their impact on and use as an instrument for the advancement and enhancement of women [19] which states, "ICTs offer tools for enhancing women's full access to the benefits of information and new technologies." It also supports the South African National Department of Education's e-Education White paper [6] 
which encourages the use of ICT to accelerate teaching and learning goals and the ICT empowerment charter $4^{\text {th }}$ working draft's objective to increase the extent to which women, communities, disabled persons, workers, cooperatives and youths participate meaningfully in all areas of the ICT sector [4].

This paper represents the results of a needs analysis on gender and socio-economic status of villagers in a South African rural area in relation to women's access to ICT education. The research question was "What impact does the socio-economic environment have on girls' and women's access to ICT education and what measures can be taken to enhance their access to ICTs". The study was undertaken in Mootse village in the Elandsdoorn area of Mpumalanga province in South Africa.

Mootse village is a semi-rural area. This village developed in the middle of nowhere, without any economic base such as industries, mines or a vibrant agriculture. It has a population of 16,000 people. The main languages of communication are Zulu, Sotho and English. The area has access to electricity, running water and has cell phone coverage. Telephone lines have reached this rural area through public call boxes and radios, televisions (TV) and newspapers are available. The community also relies on information from informal networks, but these networks do not adequately satisfy their information needs.

The village boasts of a multipurpose community medical clinic, which is funded by a number of Dutch organisations. Under the auspices of the Ndlovu Development Trust, the medical clinic runs several projects such as the vegetable garden, a nutrition program, feeding schemes for children, an old age home, welding project, an Information Technology centre, two bakeries, an HIV/AIDS awareness program, a fitness centre and a post office facility. Locals are trained in entrepreneurial skills while employed in these projects and later released into the community to start their own businesses.

\section{Research design and methodology}

A needs analysis was conducted in the form of a case study undertaken in Mootse village. A needs analysis defines the nature, size, type and scope of a problem, its indicators, the causes of the need, and the consequences of not addressing the need [3]. A case study on the other hand follows the interpretive tradition of seeing the situation through the eyes of participants.

The aim of this research was to identify and interpret socio-economic factors associated with low access to ICT education in women, and to identify and recommend strategies to overcome the problem. The case study was to understand and interpret the community relations in terms of ICT-related interactions and was interpretive and subjective. The research questions were:

Do women have access to ICTs in this community?

What is the nature of these ICTs?

What are the levels of access to these ICTs by women?

What is the relevance of ICTs in their lives?

What factors impede women's access to ICTs in this community?

Who is the responsible authority on ICT policies that impact on this community? 
What interventions need to be put in place for these impediments to be overcome? What are the consequences if these impediments are not addressed?

A total of 60 people, randomly selected, including pupils, teachers, community women and those in business, women gainfully employed in the various projects that run within the community and users of the Ndlovu clinic IT centre were interviewed and qualitative data collected. Both groups and individual interviews were held. Group interviews have the potential for discussions to develop, thus yielding a wide range of responses. The groups were of ten people or less to avoid fragmentation of groups and loss of focus.

\section{Findings on community relations}

The following community relations were identified:

\subsection{Education system.}

In South Africa the National Department of Education is responsible for education across the country as a whole, while each province has its own education department. The central government provides a framework for school policy, but administrative responsibility lies with the provinces. Power is further devolved to school governing bodies. The South African National Qualifications Framework recognises three broad categories of education, that is, General education and training which covers grades 0 to 9 in schools and basic adult literacy, Further Education and training which covers colleges offering certificates and diplomas and work-related courses in grades 10 to 12 in schools, and Higher Education and training which covers university education [1]. According to the interviewees there is a gap between policy and implementation of policy in education. An example would be a policy of computerisation of schools, which is hampered by shortage of funding for computerisation of such.

Schools run on an outcomes-based education (OBE) system [13, 1], which was introduced in South Africa in 2001. OBE is a learner-centred process that encompasses both what learners learn and are able to do at the end of the learning process. It is an activity-based approach to learning designed to promote problemsolving and critical thinking. The interviewees felt that OBE curriculum was very easy, hence students idle a lot, resulting in gross indiscipline. Student support groups such as dance groups, peer networks and sports clubs are not there in schools in this community; hence students are prone to peer pressure which in most cases exposes them to delinquency and health problems.

The secondary schools are divided into comprehensive schools that teach workrelated subjects, academic schools, technical high schools, agricultural schools and arts and culture schools. The criteria for admission into technical schools are science and engineering subjects. It is more expensive for students to register for technical courses because the equipment required is expensive and the resources to teach technical sciences limited. The shortage of equipment means that schools cannot conduct practical lessons. This is impacting greatly on the teaching of science, music and drama resulting in a high failure rate in these courses. As a result of the shortage of books and the fact that the information in textbooks is limited, coupled with the fact that schools have no computers, let alone access to the Internet, teaching of 
science subjects including ICTs is hampered. Schools are still waiting for the Project Consolidate that promises to connect all municipalities to a network for their dreams to introduce ICT education to come true.

The nearest technical college that offers work-based learning and entrepreneurial skills is over 40 kilometres from this village. That means would-be students have to contend with long distances to the college. This discourages potential students from taking up courses.

The local education system is predominantly supported by local teachers. The question of lack of opportunities outside the area for local teachers and the cultural connections brings them to work in their community of birth. The former South African "independent homelands" such as Venda and Kiyono had in place systems to produce technical teachers, hence such teachers have a good representation in this community. There are no incentives for rural teachers, hence the rural-urban migration of teachers leaves the rural community with a shortage of teachers.

\subsection{Cultural values}

If in years before the African communities believed in the extended family structure and community of purpose, this culture is slowly disintegrating particularly among the younger generation. They have access to radio, newspapers and TV, hence they are easily be influenced by external cultures. Pockets of the elderly are still battling to conserve the culture of socialism in the community and the language and practices of tradition.

Although there are two main tribes, the Zulu and Sotho living together, intertribal tolerance exists in this area. It was noted that most of the people can converse in both the languages. There are a sizeable number of members of the community, who cannot converse in English because of the high levels of illiteracy.

\subsection{HIV/AIDS issues}

HIV/AIDS is a problem in the community, with women being the most affected because they do not have a choice in sexual relationships due to male dominance in this patriarchal community. The Ndlovu clinic is heavily involved in HIV/AIDS awareness campaign, and issues antiretroviral medicines. The clinic has also established Aids support groups in the community. Because of unemployment most parents leave the community to work in bigger cities. In most cases though, it is the men that work outside the community. Due to divided families, this further exacerbates the problem of HIV/AIDS. As a result of the advent of HIV/AIDS child headed families are not uncommon in the area.

\subsection{Gender issues.}

Although women are in the majority in this rural area, the majority of them are not empowered educationally and economically. They depend on men for survival. Women are not aware of the existence of national organisations to support and protect them because awareness campaigns do not seem to reach them. Girls drop out of schools because of funding problems and because of teenage pregnancy. Although the 
new South African legislation allows girls to attend school even if they are pregnant, problems occur once they have given birth. They are forced to stay at home and rear their children if they do not have an extended family to support them. Women are not aware of government loans and bursaries for disadvantaged communities to pursue further education dreams.

\subsection{Unemployment and crime.}

The community is characterised by high unemployment levels. The only notable employers in the area are the Ndlovu medical centre, and the schools. As a result of high unemployment levels, crime is rife in the village. The nearest police station is eight kilometres away from this village, meaning there is no rapid response from police should they be alerted of any crime.

\subsection{Entrepreneurship.}

There is an effort to stimulate entrepreneurship through introduction of business subjects in schools as from Grade 8. There is no valid reason why they are not introduced earlier. On completion of school students can gain entry into level 2 of the three-year business training program in technical colleges.

There are limited opportunities to generate income in these areas. For those that start up business there is the problem of a limited market. The community is small hence businesses are not thriving as well as would like. The community does not seem to have a vision of business beyond their area. Lack of knowledge on and access to outside markets is the main problem.

\section{State of ICTs for education and training in Mootse village}

Although there are 6 primary and secondary schools in Mootse village, only one secondary school has computers. With a population of 600 students the school has only 14 computers and these are 286 's. Therefore this centre can only serve a limited number of students.

The Ndlovu medical clinic's IT centre has 8 Pentium 3 computers currently, and has 4 training sessions per day. The courses run over a term meaning that 64 people go through the training program per term. The centre trains locals in basic computing skills such as spreadsheets, wordprocessing, and access to Internet skills.. The locals pay a minimal fee towards the training, and terms of payment are relaxed. The software used currently is proprietary. The tutor explains some of the concepts in local languages. The certificate that is issued by the centre at the end of the course is not accredited by any institution.

The area has cellular network coverage and $90 \%$ of the population have access to cell phones. There are also public call boxes maintained by the state telephone service provider Telkom. Therefore there is a potential to use cell phones as e-learning tools, and as tools for disseminating community information.

The village has electricity and hence most of the homes have a television and radio. Besides receiving broadcasts from the national broadcasting stations there is a 
community radio station. The station project was initiated because radio is a popular medium for receiving community information in this area.

\section{Factors affecting women's uptake of ICT education in the community}

There are several issues that directly impact on women's access to ICTs as follows.

\subsection{Shortage of ICT teachers}

There is a shortage of ICT teachers in this community and in South Africa generally. Former teacher training institutions were incorporated into universities in 2002 and they offer a minimum of a Bachelor of Education (B.Ed.) degree. In line with the universities' mandate of access to ICTs for all, student teachers are introduced to computer literacy skills, that is access to the basic computer applications. There is no direct degree program that trains teachers in both education and ICT disciplines. To be an ICT teacher one has to further upgrade their computing skills outside the educational degree programme to diploma level or higher. Those that complete pure degree programs in ICT-related disciplines prefer to join industry than work in education, due to differences in remuneration. Entry level remuneration for a B.Ed. graduate is approximately US\$1000, while that of a computer science graduate in industry would be US\$2000. The shortage of ICT teachers affects not only the disadvantaged schools but also the advantaged schools, who are at an advantage in that they can outsource the ICT services from external consultants.

\subsection{South African Government policy on ICTs.}

Public policy on ICT in education is determined by the Department of Science and Technology (DST), the Department of Communications and the Department of Education.

The collaboration between the departments of education and communications came up with an e-Education white paper [18] and contributed to the reduction of Internet and telephone tariffs by $50 \%$ in schools. The targets set by the e-education white paper to be achieved by 2007 are to:

- Build an education and training system to support ICT integration in teaching and learning and improved management and administration.

- Build teachers' and managers' confidence in the use of ICTs

- Build a framework for competencies for teacher development in the integration of ICTs into the curriculum

- Establish an ICT presence in schools

- Ensure that schools use education content of high quality

- Ensure that schools are connected, have access to the Internet and communicate electronically

- Ensure that school communities use and support ICT facilities

The implementation of the targets set by the education white paper is still in progress, and the impact has not been felt yet in schools in this community.

The DST through its National Research and Development (R\&D) strategy (2002), the white paper on Science and Technology (1996) and the National System of 
Innovation [18] identify ICT as one key technology missions. The Joint Initiative for priority skills acquisition promotes human capital development, including in the ICT sector [7]. The DST, Department of communications and the Department of education have to work together to come up with a unified ICT strategy for schools and training institutions in order to avoid duplication of effort, and also passing the buck to one another.

South Africa lacks in the school system and does not provide the right foundation to motivate people into ICT at an early age. Most pupils in public schools do not learn the basic computer skills at school. Cost is a factor in equipping schools with ICTs. Universities are not churning out ICT students with practical training for industry. Therefore the curriculum should be revamped to meet the rising demand for ICT practitioners in industry.

\subsection{Girls' attitude towards science-related subjects}

The fact that the dominant cultural understanding of technology is as a masculine activity, means that women have often chosen not to engage with it - not because they are excluded but because it does not fit with their self image of what it is to be a woman [8]. Traditionally, anything that is difficult to perform is considered a preserve of the male species. Therefore girl children would psychologically have a barrier to taking up science subjects, including ICT education. There is a shortage of role models who have succeeded in ICT careers and can be emulated among the womenfolk in this small community. Boys have more access to technology at home than girls from a young age even in this rural community. Therefore girls have less hands-on experience in technology than boys even before they reach schools. In this light, boys are encouraged and have more positive attitudes towards ICTs than girls.

\subsection{Levels of literacy, awareness, finance and the language barrier in women}

There is a substantial number of women interviewed that could not speak English, meaning that they were illiterate. Ironically, much of the knowledge present in the global pool is in English language that is not understood by the poorest rural/tribal communities. There is very little content in the vernacular language for the nonEnglish speaking [14]. Therefore since the language of teaching in educational institutions is English, it would be difficult to impart ICT knowledge to these members. The best alternative is to enable training in local languages. But there is the mammoth task of providing content in these languages.

The new technology comes at a financial cost, which hinders its penetration to the individual and sometimes to the community. The problem is compounded by the fact that women in developing countries have little control over the household income and do not have decision-making power to invest in these technologies [14]. With high unemployment levels only a privileged few women can access paid training. Therefore financial costs hinder penetration of ICTs. Very few women in this community are aware of the benefit of taking up ICT training let alone the benefit of utilising ICT because they have not been exposed to it. 


\subsection{Access to hardware, software and support}

This community uses proprietary software in both the schools and the Ndlovu IT centre which proves very expensive to this disadvantaged people. They are not aware of the availability and benefits of open-source software. Open source is more appropriate for the technology realities in underdeveloped communities. The challenge though, is not only about software licences but also the cost of deployment and maintenance of ICT infrastructure. The schools do not have the required technical support personnel, while the medical centre's IT centre is short-staffed.

\subsection{Assessment of students}

IT and Computer Applications is a subject that is examinable at provincial levels for Grade 10 pupils, and at National level for Grade 12 pupils. But because the schools in this community do not have the ICTs to support learning then the courses cannot be taught in their school curriculum.

\subsection{Access to external organisations}

The main driving factor to acquiring ICT skills in this community is that, for employment purposes, most organisations today require their employees to have a minimum of basic level computing skills. The local women entrepreneurs have problems marketing their products, and the ability to access the Internet would enable them to access the international market, hence the need for ICT training. Also women's groups can use ICT technologies to disseminate information to other women on issues of interest.

\subsection{Use of cell phones as an e-learning tool}

There is $80 \%$ cell phone coverage in South Africa and in this community most of the people have access to cell phones. Currently the schools and the community are not taking advantage of the cellphone as an e-learning tool. The challenge faced is the cost of the relevant gadget for some of the learners if this were to be made a compulsory learning tool in this community. This should also be supported by making content readily available, but the capacity to do that does not exist.

\subsection{Criminal activities and ICTs}

The community lives in fear of theft of whatever ICT technologies they have due to the high crime rate. That would mean therefore that schools and computer centres with ICT equipment would have to invest in expensive alarm systems and surveillance cameras to scare off would-be thieves. But this equipment is beyond the reach of most of the schools, which are already underfunded. To make matters worse, the nearest police station is about 8 kilometres from this village.

\subsection{Access to electricity.}

Although the villagers have access to the electricity grid, due to the high unemployment levels, they find it difficult to pay for the electricity. Therefore that means without the funds for electricity, there is no access to ICTs in the homes. 


\subsection{Women's responsibility for family life}

Women are responsible for family life. Women's double and triple workloads of domestic, income generation and community management activities mean that they often do not have free time to travel to, learn about and use ICT. It is a challenge to balance family life and training in that it is more demanding and unless flexible arrangements are made, it is impossible to participate. In relation to gender inequalities current in the use of ICTs, fundamental issues such as lack of child care for women wishing to train have not been addressed. With the problem of parents emigrating to seek employment outside the community, girls find themselves without the support of the extended family for child care should they wish to further their ICT education

\section{Strategies to increased access to ICT education for women}

The following strategies were identified to improve access of women 's access to ICT education in the rural community of Mootse:

\subsection{Coordinated efforts of women's groups.}

As things stand women's groups in South Africa operate as autonomous entities, meaning their efforts are not coordinated. There is actually a duplication of effort. Gender desks, to mainstream gender into the public service exist separately in each of the government departments, with no collaboration between them. Therefore it is of importance to create networks of women to spearhead ICT issues as follows:

- Share experiences and opportunities

- Facilitate knowledge and access of ICTs for women

- Ensure uptake of ICT careers by women

- Partake collectively in ventures in the ICT sector to pursue common ICT objectives

The starting point for any successful gender-entrenched knowledge networking approach is the development of relationships that make it easier for women to talk about their needs, share information and work together [14]. Issues of women's confidence and competence should be addressed through these professional support networks. There should be in place strategies that are accessible to women and promoting lobbying and advocacy activities to enable them to interact with governments and each other for the promotion of their rights and concerns [9]. There should be awareness raising in women. The community should be sensitised through workshops, seminars and mass media in promoting the impact of ICT for girls and women.

The idea of a special ministry dedicated to women might not be bad. Given all problems faced by women in the South African society generally, most actions of this ministry would concentrate on social and health initiatives [12]. 


\subsection{Networks of community-based ICT learning centres}

To tackle social exclusion, setting up of a network of community-based ICT learning centres and multiple access points to complement any access in schools for those who would not normally access mainstream educational opportunities would suffice. This would help women avoid having to travel long distance to access ICT training. This will also help increase access to ICT, help people develop ICT skills and open further opportunities for learning and employment. There is recognition that large sections of the community are not able to afford the necessary skills to take advantage of the potential that ICTs have to offer them. The community-based ICT facilities are a strategic tool in this.

\subsection{Overcome barriers.}

There are a number of barriers to entry to ICT education and training for women. One is the language barrier. With the high levels of illiteracy among women, it is likely that a large number of them cannot communicate in English. But since English is the norm in training in South Africa, this might be a barrier to ICT training. Also, insisting on specified minimum educational entry requirements into training could deter those that do not meet the criteria. Achieving a women-friendly information society comprises also developing content that speaks to women's concerns and reflects their knowledge, language and cultural contexts [9].

\subsection{Professional development for teachers.}

In line with the South African government policy on building teachers' confidence in the use of ICTs, at school level, professional development for teachers needs to give teachers enough understanding of how computer technology works and its basic concepts so that they are empowered to deliver to their girls and women. The teacher of today is inhibited in exploiting ICT by the lack of suitable teaching and learning environments. Professional development of teachers has to be carried out through development of competencies in their use and in their integration in discipline teaching. Therefore the same policy of building an education and training system to support ICT integration in teaching and learning and improved management and administration is essential.

\subsection{Enabling environment.}

Creating an enabling environment for ICT in education access and strategy which will reach this socio-economic group would entail policies which support access. The relative price of capital to the poor should be reduced by improving access to training, extending the electricity grid to the low-income areas and by granting selective and temporary subsidies to poor users. Fostering competition in the telecommunication sector reduces communication costs and this improves physical access to ICTs by the poor. Providing schools with technology infrastructure and a considerable number of teachers with ICT basic skills, and technical personnel to manage the laboratories would go a along way to create an enabling environment for ICT education for women. 


\subsection{Redefinition of ICT skills.}

There has been a tendency in industry, government, the media and educational institutions to translate the shortage of It workers of professionals into a shortage of computer scientists and engineers, in spite of the evidence that IT managers, database administrators, etc are also in demand [2]. ICT skills focus on Computer Science, robotics and engineering and exclude other disciplines and yet there is room for "soft skills" and interdisciplinary approaches such as finance, information systems, telecommunications, e-commerce, ICT management, database administration, etc. Females are more attracted to disciplines where there is application of technology rather than technical bits. To attract a female population, the disciplines constructed as "male" over female disciplines should not be overrated. Preliminary work conducted by Randall, et.al. [15], for instance, seems to indicate that curricula involving multidisciplinary applications will attract a higher percentage of women. There should be interaction of industry, professional associations, educational institutions and media which produce these discursive patterns. Dennis emphasized the growing demand for "hybrids", a cadre of information systems professionals with knowledge and skills in technology, business management and interpersonal skills to effectively lead organisational integration and process re-engineering activities [5].

\section{Conclusions}

The aims and objectives of this research are clearly tied to the issue of empowerment of women through ICTs. Without the full participation of its citizens, be it men or women, South Africa cannot develop. This study gave an analysis of the state of ICT education for women in rural Mpumalanga province and came up with strategies on how to improve rural women's access to ICTs.

\section{References}

1. About S.A. Education, www.info.gov.za/education.htm UNIFEM. Progress of the world's women, New York, United Nations, 2000.

2. Cukier, W., Constructing the IT skills shortage in Canada : the implications of institutional discourse and practices, 2000.

3. Cohen, L., Manion, L., Morrison, K., Research Methods in Education, RoutledgeFalmer Taylor and Francis Group, ISBN 0-415-19541-1, 2000.

4. Denton, M., Vloeberghs, D., Leadership challenge for organisations in new South Africa, Leadership and development Journal, Vol. 24, No. 2, 2000.

5. Dennis, L.M.S., Trauth, E.M., Farwell, D., Critical skills and knowledge requirements of information society professionals: a joint academic/industry investigation, MIS Quarterly, Vol. 19, No. 3, pp 313-330, 2000.

6. E-education white paper, www.dst.gov.za/publications/reports/

7. Joint initiative for priority skills acquisition, www.info.gov.za/otherdocs/2007/jipsarep.pdf

8. Herman, C., From visions to reality : changing women's perspectives at the village hall, Computers and Society, pp. 15-22, December 2001.

9. Huyer, S., Women, ICT, and the information society: global perspectives and initiatives, Women and ICT, Baltimore, 2005.

10. International Telecommunications Union, Preparing the way: gender in summit, ITU Telecommunications Development Bureau, Geneva, 2003. 
11. Kenny, C.J., Information Technology for Development, Vol. 9, pp 25-31, 2000.

12. Medeiros, C.B., From subject of change to agent of change - women and IT in Brazil, Women and ICT, Baltimore, 2005.

13. Mokhaba, M.J., Outcomes-based education in S.A. since 1994: Policy objectives and implementation complexities, $\mathrm{PhD}$ thesis, University of Pretoria, South Africa, 2005.

14. Pattanaik D., Engendering knowledge networks - empowering women through ICT, Proceedings of Women and ICT, Baltimore, 2005

15. Randall, C, Price, B., Reichgelt, H., Women in computing programs : does the incredible shrinking pipeline apply to all computing programs? Inroads ACM SIGCSE Bulleting, Vol. 35, No. 4, pp 55-59, 2003.

16. Roman, R., Colle, R.D., Content creation for ICT development projects: integrating normative approaches and community demand, Information Technology for Development, Vol. 10, pp 85-94, 2003.

17. United Nations Millennium Declaration, General assembly resolution 55/2 of 8 September 2000, Office of the UN High Commission for Human Rights, UN Headquarters, New York, 2000.

18. White paper on Science and Technology, www.dst.gov.za/publications/Science_Technology_White_Paper.pdf, 2007.

19. $47^{\text {th }}$ session of the Commission of Status of women, 3-14 March 2003, UN Headquarters, New York, 2003 